\title{
FEVER AND LEUKOCYTOSIS: PHYSICAL MANIFESTATIONS OF BIPOLAR AFFECTIVE DISORDER?
}

\author{
ZIAD KRONFOL ${ }^{1}$, GHADA HAMDAN-ALLEN ${ }^{2}$ and DONALD W. BLACK \\ 1 Departwent of Psychiatry, University of Michigan Medical Center \\ Ann Arbor, Michigan, U.S.A. \\ ${ }^{2}$ Department of Psychiatry, University of Towa College of \\ Medicine, Iowa City, Iowa, U.S.A.
}

(F1nal form, March 1988)

\begin{abstract}
Kronfol, Zlad, Ghada Hamdan-Allen and Donald W. Black: Fever and leukocytosis: Physical. manifestations of bipolar affective disorder? Prog. Neuro-Psychopharmacol. \& Biol. Psychiat. $1988,12: 887-891$

1. Fever and leukocytosis are occasionally observed in patfents with psychiatric disorders. A thorough medical evaluation does not always reveal the origin of these abnormalities.

2. We report the case histories of three patients with bipolar affective disorder and an abnormal DST who had fever and leukocytosis during the acute phase of their 111ness. No organic etlology could be found.

3. All three patients responded to ECT with resolution of the depresston, the fever, and the leukocytosis, and normalization of the DST.

4. We propose that fever and leukocytosis may be rare physical manifestations of bipolar affective disorder, particularly in patients with abnormal DST.
\end{abstract}

Keywords: Bipolar Affective Disorder, Depression, Dexamethasone Suppression Test, Fever, Leukocytosis.

Abbreviations: Cerebrospinal Flufd (CSF), Computerized Tomography (CT), Electroconvulsive Therapy (ECT), Electroencephalography (EEG), Dexamethasone Suppression Test (DST), White Blood Ce11 (WBC).

\section{Introduction}

Fever and leukocytosis are not common manifestations of psychlatric 111ness. In fact, their occurrence In a psychiatric context usually alerts the physictan to the possibility of an underlying organic etlology to the psychlatric disorder. A thorough medical workup of ten points to an accompanying infectious, toxic or neoplastic process that either causes or merely accompanies the psychosis. Treatment of the infection or other organic factor may result in the clearance of the psychosis. In many instances, however, no specific organic etiology for either the fever or the leukocytosis can be found. This situation leaves both the attending psychiatrist and the medical/neurological consultant uncertain about the origin of the fever and leukocytosis, and of ten results in a delay In the effective treatment of the psychiatric condition. We now present the case historles of three patients with affective disorder whose fever and leukocytosis seem to be related to their psychiatric 111ness per se and not to an accompanying medical or neurologic disordex. 


\section{Case Reports}

\section{Case \#1}

Mr. A is a 36 year old man with a long history of bipolar affective disorder. He was maintained on 1ithium prophylaxis, but poor compliance had resulted in multiple hospitalizations. On the day of admission, he was brought to the emergency room by the police because of inappropriate and disturbing behavior. Mental status exam revealed irritab1ltty, incoherence, racing thoughts, distractability, hypersexuality and auditory hallucinations. His 1ithlum level was $0.12 \mathrm{mEq} / 1$. Pertinent physical findings were an oral temperature of $36.8^{\circ}$ $C$, a pulse of 136 and exaggerated deep tendon reflexes b1laterally. H1s white blood cell (WBC) count was $14,600 \mathrm{cel1s} / \mathrm{mm}^{3}$ with $84 \%$ neutropht1s. Medical workup Including 6/60, 12/60, blood and urine cultures, cerebrospinal fluld (CSF) studies, chest X-ray, electroencephalography (EEG) and head computerized tomography (CT) were all normal. The dexamethasone suppression test (DST) was abnormal (Table 1). The patient met diagnostic criteria for b1polar affective disorder, mantc type as established by the American Psychiatric Association's Diagnostic and Statistical Manual, Third Edition, 1980 (DSM-III). Treatment with 1ithium carbonate (with therapeutic blood levels) and neuroleptics was ineffective. He was therefore given a course of 6 unilateral electroconvulsive therapy (ECT) sessions. Following ECT, his mood became neutral,his psychosis had cleared, and both the fever and leukocytosis had resolved. A repeat DST was normal (Table 1). He was maintained on 11thfum prophylaxis with no further complications.

Case \#2

Ms. B, a 20 year old woman with bipolar affective disorder, was maintained on trazodone and lithium carbonate. Ten days prior to admission, she became mute, noncommuntcative, refused food and displayed waxy flexibility. Temperature on admission was $38.5^{\circ} \mathrm{C}$ and the WBC count was $19,500 / \mathrm{mm}^{3}$ with $86 \%$ neutrophils. Lithium level was $0.75 \mathrm{mEq} / 1$. The DST was abnormal. Laboratory investigation including $6 / 60,12 / 60$, blood, CSF and urine cultures, chest $x-r a y$ and head CT were all normal. The diagnosis of atyplcal bipolar affective disorder with catatonic features was made. The patient responded to a course of 8 bilateral ECT's with a complete resolution of catatonia, fever, leukocytosis, and normallzation of the DST(Table 1). She was discharged on lithium and carbamazepine and her temperature and WBC count remained within normal limits.

Case \#3

Mr. C, a 56 year old man with no prior history of psychiatric 1llness, presented with a two-month history of dysphorla, hypersomnia and generalized lack of tnterest. The inttial mental status exam revealed depressed mood, psychomotor retardation and persecutory delusions. The DST was abnormal (Table 1). The diagnosis of primary affective disorder with mood incongruent psychosis was made and the patient was treated with desipramine $200 \mathrm{mg}$ qhs, and haloperidol $20 \mathrm{mg}$ dally. Five days later, he developed restlessness and insomnla, and exhibited euphorfa, grandiosity and push of speech. Desipramine was discontinued and 11thium carbonate $1200 \mathrm{mg}$ daily was initlated. One week later, he became mute and diaphoretic and shot a temperature of $39.1^{\circ} \mathrm{C}$. His WBC count was $14,900 / \mathrm{mm}^{3}$ with a normal differential. Lithium level was $0.8 \mathrm{mEq} / 1$. Chest $x$-ray, serologic tests, blood, urine, sputum and CSF 
cultures were all negatlve. Head CT was normal. All medications were discontinued and a course of 12 bllateral ECT's was given. The mental status returned to baseline and the fever and leukocytosis cleared (Table 1). A repeat DST was not done. He was discharged on imipramine and fluphenazine with no recurrence of fever or leukocytosis.

Table 1

Temperature, WBC Count with Differential and Cortisol Values During the Acute Phase of Affective IIIness and Following Recovery

\begin{tabular}{|c|c|c|c|}
\hline & Case 1 & Case 2 & Case 3 \\
\hline \multicolumn{4}{|l|}{ Acute Phase } \\
\hline Temperature $\left({ }^{\circ} \mathrm{C}\right)$ & 38.6 & 38.5 & 39.1 \\
\hline WBC Count $\left(/ \mathrm{mm}^{3}\right)$ & 14,600 & 19,500 & 14,900 \\
\hline WBC D1fferent1a1 (\%) & & & \\
\hline Neutrophils & 84 & 86 & 71 \\
\hline Lymphocytes & 9 & 6 & 24 \\
\hline Cort1sol Values* (ug/d1) & 19.4 & 10.1 & 19.8 \\
\hline \multicolumn{4}{|l|}{ Recovery Phase } \\
\hline Temperature $\left({ }^{\circ} \mathrm{C}\right)$ & 37.3 & 37.0 & 37.2 \\
\hline WBC Count $\left(/ \mathrm{mm}^{3}\right)$ & 7,400 & 9,400 & 7,300 \\
\hline WBC Differential (\%) & & & \\
\hline Neutrophfls & 56 & 62 & 62 \\
\hline Lymphocytes & 29 & 21 & 25 \\
\hline Cortisol Values* (ug/d1) & 2.14 & 1.2 & $* *$ \\
\hline
\end{tabular}

*the highest of two plasma cortisol values obtained at 0800 hour and 1600 hour the day following the admintstration of $1.0 \mathrm{mg}$ of dexamethasone p.0. at 2300 hour. **data not avallable.

\section{Discussion}

The three patients described above have several features in common. All three patients carry the diagnosts of bipolar affective disorder. They all had abnormal DST results. None of them responded to conventional pharmacotherapy including 11thium carbonate, tricyclic antidepressants and neuroleptics, but all three responded to ECT. They all had a temperature of $\geqslant 38.5^{\circ} \mathrm{C}$ and a WBC count of $>14,000 / \mathrm{mm}^{3}$ during the acute phase of their 111ness. Both fever and leukocytosis cleared with the affective episode following ECT. Fever and leukocytosis did not recur when 11 thium and/or other drugs were reinstituted prophylactically.

The etfology of both fever and leukocytosts is unclear. Common causes of fever and leukocytosis such as infection, toxicity or neoplasm were not evident. Furthermore, reversal of fever and leukocytosis with ECT argues against such etlological factors. Lithium carbonate has occasionally been assoclated with leukocytosis (Murphy et al., 1971), but hyperthermia does not usually occur except in cases of 11thlum toxiclty, which was not the case in any of our patients. Leukocytosis without fever has also been reported in patients with manic $111-$ ness who have never been treated with 11thlum (Kronfol et al., 1986). The neuroleptic mallg- 
nant syndrome is usually mantfested by hyperthermia, increased muscular tonicity and may be accompanled by leukocytosis (Guze and Baxter, 1985). This syndrome however occurs In relation to neuroleptic intake. Only patient $\$ 3$ had been on neuroleptic treatment (haloperidol $20 \mathrm{mg}$ dally) when the fever and Ieukocytosis developed. This patient, however, did not exhibit increased muscular tone, a cardinal feature of the neuroleptic malignant syndrome. Catatonia can be accompanfed by hyperthermla (Powers et al., 1976), but leukocytosis 1s not a typical feature (Regestein et al., 1977). Furthermore, catatonia is not a diagnosis in 1tself (Gelenberg, 1976) and is most comonly associated wth affective disorder (Abrams and Taylor, 1976). The combination of lithium and haloperidol has been reported to produce neurotoxicity with fever and leukocytosis (Cohen and Cohen, 1974), but a careful review of these data indicate that the neurotoxicity was probably due to toxic 11thium levels (Spring and Franke1, 1981). Fever and leukocytosis have not been reported to occur together as complications of 11thium therapy when 11thium levels were maintained within the therapeutic range.

We therefore propose that both fever and leukocytosts were physical manifestations of bipolar affective disorder. Temperature control and neuroendocrine regulation are both hypothalamic functions. The neuroendocrine system exerts considerable control over the hematologic and immune system, particularly the regulation of the traffic of leukocytes in the blood stream. More specifically, glucocorticolds increase the number of circulating neutrophils and decrease the number of circulating lymphocytes (H111s et al., 1948). S1milar changes have been documented In patients with depresstve 111ness (Kronfol et al., 1984), particularly those with hypercortisolemia (Kronfol et al., 1985). A possible clue to the hypothalamic-pituitary-adrenocortical link in the etlology of both fever and leukocytosis in our patients is that all three of them had abnormal DST results during the acute phase of their 111ness when fever and leukocytosis were evident. Once the psychosis had cleared, temperature and leukocyte count returned to normal, and the DST normallzed in the two patients on whom results were avaflable. No infectlous, metabolic, toxic or neoplastic factor could be identified. Fever and leukocytosis may thus be an integral part of the $111-$ ness in some patients with bipolar affective disorder, particularly those with abnormal DST results.

\section{Conclusion}

Fever and leukocytosis are occasionally observed in patients with psychiatric disorders. A thorough medical evaluation does not always point out the origin of the fever and increased WBC count. We report the case histories of three patients with bipolar affective disurder who, when 111, had fever, leukocytosis, and abnormal DST results. An extensive medical workup to determine the origin(s) of both fever and leukocytosis was essentially non-revealing. Both fever and leukocytosis cleared and the DST results normalized following successful treatment of the affective IIlness with ECT. We propose that fever and leukocytosis may be rare phystcal manifestations of the acute phase of an affective disorder, particularly if the disorder is accompanled by catatonic features and/or an abnormal DST. 


\section{References}

ABRAMS, R. and TAYLOR, M.A.

(1976)

Catatonia: A prospective clinical study. Arch Gen Psychlatry 33: 579-581.

AMERICAN PSYCHIATRIC ASSOCIATION (1980) Task Force on Nomenclature and Statist1cs, Diagnost1c and Statistical Manual of Mental Disorders, Th1rd Edition (DSM-III), American Psychlatric Association Press, Washington, D.C.

COHEN, W.J. and COHEN, N.H. (1974) L1thium carbonate, halopertdol and trreversible bratn damage. J Am Med Assoc 230: 1283-1287.

GELENBERG, A.J. (1976) The catatonlc syndrome. Lancet $\underline{1}$ : 1339-1341.

GUZE, B.H. and BAXTER, L.R. (1985) Neuroleptlc malignant syndrome. New England J Med 313: 163-166.

HILLS, A.G., FORSHAM, P.E. and FINCH, C.A. (1948) Changes in circulating leukocytes inducec by the administration of pituitary adrenocorticotrophic hormone (ACTH) in man. Blood 3 : 755-768.

KRONFOL, Z, TURNER, R., NASRALLAH, H. and WINOKUR, G. (1984) Leukocyte regulat1on in depression and schizophrenia. Psychlat Res 13: 13-18.

KRONFOL, Z., NASRALIAH, H., CHAPMAN, S. and HOUSE, J.D. (1985) Depression, cortisol metabo11sm and 1ymphocytopenia. J Affect Dis 9: 169-173.

KRONFOL, Z., TURNER, R., HOUSE, J.D. and WINOKUR, G. (1986) Elevated blood neutroph11 concentration in mania. J C1In Psychiat 47: 63-65.

MURPHY, D.L., GOODWIN, F.K. and BUNNEY, W.E. (1971) Leukocytosis during lithium treatment. Am J Psychiat 127: 1559-1561.

POWERS, R., SCOTT, DOUGLASS T. and WAZIRI, R. (1976) Hyperpyrexia in catatonic states. Dis Nerv Syst 37: 359-361.

REGESTEIN, Q.R., ALPERT, J.S. and REICH, P. (1977) Sudden catatonic stupor with disastrous outcome. J Am Med Assoc 238: 618-620.

SPRING, G. and FRANKEL, M. (1981) New data on 11thium and haloperidol incompattbilfty. Am J Psychlat 138: 818-821.

Inquiries and reprint requests should be addressed to:

Z1ad Kronfol, M.D.

1500 E. Medical Center Drive

UH-9C/Room 9150 Box 0120

Ann Arbor, MI 48109-0120, U.S.A.

(313) $936-4960$ 